\title{
Event Occurrence Indicator
}

National Cancer Institute

\section{Source}

National Cancer Institute. Event Occurrence Indicator. NCI Thesaurus. Code C82438.

An indication of whether or not an event has taken place. 